\title{
The significance of Siglec-15 expression in resectable non-small cell lung cancer
}

\begin{abstract}
J. Q. $\mathrm{HAO}^{1,2, *,}$, J. Y. NONG ${ }^{3, *}$, D. ZHAO ${ }^{4, *}$, H. Y. LI ${ }^{1}$, D. SU ${ }^{4}$, L. J. ZHOU ${ }^{4}$, Y. J. DONG ${ }^{4}$, C. ZHANG ${ }^{4}$, N. Y. CHE ${ }^{4}$, S. C. ZHANG ${ }^{1}$, J. Z. LIN ${ }^{5,6,7,8}$, J. B. YANG ${ }^{5,8, *}$, H. T. ZHANG ${ }^{9, *}$, J. H. WANG ${ }^{1, *}$

${ }^{1}$ Department of Medical Oncology, Beijing Chest Hospital, Capital Medical University, Beijing Tuberculosis and Thoracic Tumor Research Institute, Beijing, China; ${ }^{2}$ Department of Respiratory Medicine, Qingyang People's Hospital, Gansu, China; ${ }^{3}$ Department of Thoracic Surgery, Xuanwu Hospital, Capital Medical University, Beijing, China; ${ }^{4}$ Department of Pathology, Beijing Chest Hospital, Capital Medical University, Beijing Tuberculosis and Thoracic Tumor Research Institute, Beijing, China; ${ }^{5}$ The Cancer Center, Union Hospital, Fujian Medical Center, Fuzhou, Fujian, China; ' Immunotherapy Research and Development, CreMab Biopharma, Inc, Fuzhou, China; ${ }^{7}$ The Immunotherapy Institute, Fujian Medical University, Fuzhou, Fujian, China; ${ }^{8}$ Department of Otolaryngology, Cancer Center, University of Minnesota Medical School, Minnesota, MN, USA; ${ }^{9}$ Department of Central Laboratory, Beijing Chest Hospital, Capital Medical University, Beijing Tuberculosis and Thoracic Tumor Research Institute, Beijing, China
\end{abstract}

*Correspondence: jinghuiwang2006@163.com; zhtbeijing@163.com; yangx142@umn.edu

${ }^{\#}$ Contributed equally to this work.

Received February 20, 2020 / Accepted April 29, 2020

\begin{abstract}
Siglec-15 (S15) is another important mechanism of tumor immune escape besides the PD-L1/PD-1 pathway and represents a new kind of immune checkpoint inhibitor. However, the associations of tumor Siglec-15 expression with clinicopathological characteristics and outcomes of non-small cell lung cancer (NSCLC), and tumor-infiltrating lymphocytes (TILs) in a tumor microenvironment (TME) have so far been unclear. A total of 324 NSCLC surgical samples on tumor microarray were used in this study for investigating the association of S15 expression with clinicopathological characteristics and overall survival (OS) as well as correlation with TILs using multiplex immunofluorescence staining and PD-L1. Results showed that the expression of S15 in adenocarcinoma was significantly higher than that in squamous cell carcinoma. S15 expression was positively correlated with $\mathrm{CD}^{+} \mathrm{T}$ cell density in the stroma. The expression rate of PD-L1 in lung squamous cell carcinoma was higher than that in lung adenocarcinoma. S15 expression was not associated with the prognosis of early NSCLC. The pathological mechanism of the co-expression of S15 and PD-L1 in resectable NSCLC remains to be further studied.
\end{abstract}

Key words: NSCLC, Siglec-15, TILs, multiplex immunofluorescence staining

Lung cancer is the leading cause of cancer death in the world. The five-year survival rate of distant metastasis lung cancer is only $5 \%$. For decades, platinum-based chemotherapy has been the cornerstone of the treatment of metastatic lung cancer. In the past decade, targeted therapy has brought significant clinical effects and benefits for non-small cell lung cancer (NSCLC) accompanied by oncogene driven mutations, such as EGFR, ALK, ROS1, and more targeted drugs, including BRAF, MET, RET, HER-2, and NTRK $[1,2]$. PCR based on small samples or a comprehensive gene test based on next generation sequencing has become a routine method to select patients who meet the target treatment conditions.

In recent years, immunotherapy based on immune checkpoints, such as programmed cell death 1 (PD-1) and programmed cell death ligand 1 (PD-L1), had been demonstrated to prolong overall survival (OS) for a subset of NSCLC patients, especially without sensitive oncogenic driver genes. Immune checkpoint inhibitors (ICIs), including pembrolizumab, nivolumab, atezolizumab, and durvalumab, had been approved by the American FDA for treatment in lung cancer [3-12]. For patients who received pembrolizumab, the fiveyear OS rate of previously untreated patients with lung cancer achieved $23.3 \%$ and the median OS of patients with tumor proportion score (TPS) $\geq 50 \%$ of PD-L1 expression was 35.4 months and 5-year survival rate was $29.6 \%[13,14]$.

Immunotherapy alone or combined with chemotherapy or anti-vascular drugs has become an important treatment for lung cancer and has been widely used. However, only about $20 \%$ of NSCLC patients benefit from ICIs, and good predictors of ICIs are very challenging in clinical practice, although PD-L1 expression and tumor mutation burden were considered with a certain degree of prediction in ICIs [15]. The possible reason is that more than one immune 
checkpoint in a considerable number of cases suppresses the local immune response of the tumor, such as Siglec-15 (S15), PD-L1, and CTLA-4, etc. [16]. The PD-1/PD-L1 pathway is the major checkpoint of immunotherapy, which accounts for less than $40 \%$ of the immune escape mechanism of cancer $[17,18]$.

S15 is one of the members of Siglec gene family. In addition to the PD1/PD-L1 pathway, S15 is mainly expressed on tumor cells. It is a different escape pathway from PD-1/ PD-L1 by inhibiting T cell function, which may be a potential target of immunotherapy [19]. Phase I of a clinical trial of the S15 inhibitor, NC318, is in progress (NCT03665285). It blocks the S15/Sialyl-T antigen (sTn) signaling pathway, normalizes the immune microenvironment, and restores the function of the immune system to kill tumor cells. Tumor microenvironment (TME) is composed of tumor cells, tumor-infiltrating lymphocytes (TILs), vascular cells, stromal fibroblasts, and so on. Among them, $\mathrm{CD}^{+} \mathrm{T}$ cells and FOXP3 ${ }^{+} \mathrm{T}$ cells are important TILs. The former is the positive force of tumor immune response, while the latter is the negative force of tumor immune response. Up to date, the association of S15 expression with clinicopathological characteristics and outcomes of NSCLC is unknown and the relationships of S15 expression with TILs in tumor microenvironment remain unclear.

This study aimed to investigate the significance of S15 expression with the clinicopathological and prognosis of patients with NSCLC and TILs. The relationship between S15 and PD-L1 expression was also evaluated.

\section{Patients and methods}

Patient cohort. All patients were hospitalized in Beijing Chest Hospital from 2006 to 2016. Inclusion criteria: newly diagnosed as primary NSCLC, untreated before the operation, with follow-up data. Exclusion criteria: insufficient tissue, combined with other malignant tumors. Staging according to AJCC Cancer staging ( $8^{\text {th }}$ edition) [20]. According to WHO Guidelines [21], NSCLC is classified by subtype. This study was approved by the Ethics Committee of Beijing Chest Hospital.

Multiple immunofluorescence staining and analysis. We stained $4 \mu \mathrm{m}$ thick tumor tissue microarray (TMA) sections, which we continuously resected, using Opal 7-color reagents (PerkinElmer, Inc. Waltham, Massachusetts, US) and antibodies (including S15, CD8, FOXP3, and cytokeratin $[\mathrm{CK}])$. The method we used for TMA was the same as in our previous work [22]. The procedures are as follows: firstly, TMA slices were heated for $6 \mathrm{~h}$ at $60^{\circ} \mathrm{C}$ in an electric blast drying oven, dewaxed with xylene for three times $(10 \mathrm{~min}$ each time), then rewatered with graded ethanol (100\% $2 \mathrm{~min}$; 100\% 2 min; 95\% 2 min; 90\% 2 min; 85\% 2 min; 80\% 2 min), and washed twice with ultra-pure water. We pretreated the sections using antigen retrieval solution in a microwave oven, first bringing the buffer to the boiling point at $100 \%$ power and then continuing for $15 \mathrm{~min}$ at $20 \%$ power. After blocking them with blocking buffer for $25 \mathrm{~min}$, we incubated the slides with the first primary antibody for $2 \mathrm{~h}$ at room temperature (RT), and then washed them 3 times in Tris-buffered saline + Tween 20 (TBST). Slides were further incubated with the appropriate secondary antibody (Opal Polymer HRP Ms + $\mathrm{Rb}$ ) for another $30 \mathrm{~min}$ at RT and washed as described above.

Next, to generate the Opal signal, we incubated the slides with Opal working solution (10 $\mathrm{min}$ at RT) and washed them 3 additional times in TBST. Before the next marker staining, the sections were treated in the microwave oven, and then we repeated the above steps. After the last antigen retrieval treatment, the sections were stained with DAPI for $5 \mathrm{~min}$, washed once with TBST for $10 \mathrm{~min}$, and then coverslipped [23]. The primary antibodies were CD8 (clone EP334, dilution 1:600; ZSBIO, Beijing, China), S15 Polyclonal Antibody (PA5-72765, dilution 1:800; Invitrogen, Carlsbad, California, US), FOXP3 (clone 236A/E7; dilution 1:600; Abcam, Cambridge, UK), and CK (clone PAN-CK [Cocktail], dilution 1:1000, Abcam).

The stained slides were scanned by Vectra multispectral microscope (PerkinElmer). Fluorescence spectroscopy acquired by single-color stained continuous tissue sections under the same shooting conditions, then, the inForm software 2.2.0 (PerkinElmer) was used to remove autofluorescence and analyze the fluorescence for the multicolor immunofluorescence stained slides. The images were analyzed in two compartments (defined by CK staining): tumor compartments and stromal compartments identified by applying the tissue segmentation tool of the inForm software. Distinguishing of the tumor and stromal compartments and cells was performed by trained pathologists. The individual cells (defined by DAPI staining) were identified by the cell segmentation tool. Data of $\mathrm{S} 15^{+}$cells, $\mathrm{CD} 8^{+}$ $\mathrm{T}$ cells, FOXP3 ${ }^{+} \mathrm{T}$ cells in each TMA core including tumor or stroma were collected. Because of less specificity of S15 expression strained with polyclonal antibody in the stroma, the data of S15 expression in the stroma were not analyzed. In each tumor, every marker expression was analyzed by the density that was calculated by the percentage of positive cells in total tumor cells or total stromal cells and entered statistical analysis.

PD-L1 immunohistochemistry (IHC). PD-L1 (clone 22C3, Dako North America, Inc.) expression was tested on TMA consecutive sections on Autostainer Link 48 machine (Dako North America, Inc.) combined with Dako EnVisionTM FLEX ${ }^{+}$and DAB Enhancer solution according to the manufacturer's instructions. PD-L1 expression equal or greater than $50 \%$ in tumor cells was regarded as PD-L1 positive and expression less than $50 \%$ in tumor cells was negative. The PD-L1 expression was confirmed by two trained pathological doctors.

Statistical analysis. $\chi^{2}$ test was used to analyze the association of categorical variables. Wilcoxon test was used to analyze the association of non-normal distributions 
measurement data and categorical variables. Spearman's rank correlation was used to analyze the correlation of quantitative data. Kaplan-Meier method was used to analyze the OS and log-rank was for intergroup comparison. Cox hazard proportion model was performed for multivariate analysis. Two-side $\mathrm{p}<0.05$ was regarded statistically significant difference. Data were analyzed in SPSS software v21.0, R software v3.6.0, and GraphPad Prism v8.0.

\section{Results}

Patients. 324 patients with primary NSCLC were enrolled. $218(67.3 \%)$ were males and $106(32.7 \%)$ were females. The median age was 61 years old (range, 28-84), 183 (56.5\%) were equal or greater than 60 years old. $173(53.4 \%)$ patients were smokers. 89 patients were with stage I (27.5\%), 58 were II (17.9\%), 158 were III (48.8\%), and 19 were IV (5.9\%). 105 patients were with $\mathrm{T} 1$ stage $(32.4 \%), 120$ were $\mathrm{T} 2(37.0 \%)$, 51 were T3 (15.7\%), and 48 were T4 (14.8\%). 155 patients were with N0 stage (47.8\%), 31 were N1 (9.6\%), 136 were N2 $(42.0 \%)$, and 2 were N3 (0.6\%). Lung adenocarcinoma was diagnosed in $230(71.0 \%)$ and lung squamous cell carcinoma in $94(29.0 \%)$ patients. $156(45.3 \%)$ patients received postoperation chemotherapy and 188 (54.7\%) did not receive adjuvant chemotherapy (Table 1 ).

The significance of S15, CD8, FOXP3, and PD-L1 expression with the clinicopathological characteristics. Tumor S15 expression was significantly higher in lung adenocarcinoma than that in lung squamous cell carcinoma $(\mathrm{p}=0.004)$. No differences between the density of $\mathrm{S} 15^{+}$tumor cells with age, gender, smoking, and stage were observed. The density of tumor $\mathrm{CD}^{+} \mathrm{T}$ cells significantly increased with ageing $(\mathrm{p}=0.001)$, decreased with stage $(\mathrm{p}=0.031)$, and $\mathrm{T}$ stage $(\mathrm{p}=0.041)$. The density of tumor $\mathrm{CD} 8^{+} \mathrm{T}$ cells was significantly higher in the PD-L1 positive group ( $\mathrm{p}=0.002)$. The density of tumor FOXP $3^{+} \mathrm{T}$ cells decreased significantly with the $\mathrm{T}$ stage $(\mathrm{p}=0.014)$. The density of stromal FOXP $3^{+}$ $\mathrm{T}$ cells was significantly higher in males $(\mathrm{p}=0.014)$, smokers $(\mathrm{p}=0.002)$, and lung squamous cell carcinoma $(\mathrm{p}<0.001)$, decreased with the stage $(\mathrm{p}=0.019)$, and T stage $(\mathrm{p}=0.027)$. We found that the rate of the PD-L1 expression increased significantly with the $\mathrm{T}$ stage $(\mathrm{p}=0.034)$, and higher in lung squamous cell carcinoma ( $\mathrm{p}=0.006$, Figures $1-5$; Supplementary Tables 1,2).

The correlation of density of $\mathrm{S}^{+} 5^{+}$cells, $\mathrm{CD8}^{+} \mathrm{T}$ cells, FOXP3 $^{+} \mathrm{T}$ cells. The density of tumor $\mathrm{S}^{+} 5^{+}$cells was positively correlated with the density of stromal $\mathrm{CD} 8^{+} \mathrm{T}$ cells $(\mathrm{r}=0.238, \mathrm{p}<0.001)$. The density of tumor $\mathrm{CD}^{+} \mathrm{T}$ cells was positively correlated with the stromal $\mathrm{CD} 8^{+} \mathrm{T}$ cells $(\mathrm{r}=0.635$, $\mathrm{p}<0.001)$, tumor $\mathrm{FOXP}^{+} \mathrm{T}$ cells $(\mathrm{r}=0.286, \mathrm{p}<0.001)$, and stromal FOXP3 ${ }^{+} \mathrm{T}$ cells $(\mathrm{r}=0.315, \mathrm{p}<0.001)$. The density of stromal $\mathrm{CD}^{+} \mathrm{T}$ cells was positively correlated with the density of stromal FOXP3 ${ }^{+} \mathrm{T}$ cells $(\mathrm{r}=0.283, \mathrm{p}<0.001)$. The density of tumor FOXP3 $3^{+} \mathrm{T}$ cells positively correlated with the stromal FOXP3 ${ }^{+} \mathrm{T}$ cells $(\mathrm{r}=0.387, \mathrm{p}<0.001)$. No correla-
Table 1. Patients' characteristics.

\begin{tabular}{|c|c|c|}
\hline Variables & Number & $\%$ \\
\hline \multicolumn{3}{|l|}{ Age (years) } \\
\hline Range & $28-84$ & \\
\hline Median & 61 & \\
\hline$<60$ & 141 & 43.5 \\
\hline$\geq 60$ & 183 & 56.5 \\
\hline \multicolumn{3}{|l|}{ Gender } \\
\hline Male & 218 & 67.3 \\
\hline Female & 106 & 32.7 \\
\hline \multicolumn{3}{|l|}{ Smoking status } \\
\hline Non-smoking & 151 & 46.6 \\
\hline Current smoking & 173 & 53.4 \\
\hline \multicolumn{3}{|l|}{ Stage } \\
\hline I & 89 & 27.5 \\
\hline II & 58 & 17.9 \\
\hline III & 158 & 48.8 \\
\hline IV & 19 & 5.9 \\
\hline \multicolumn{3}{|l|}{ T staging } \\
\hline $\mathrm{T} 1$ & 105 & 32.4 \\
\hline $\mathrm{T} 2$ & 120 & 37.0 \\
\hline $\mathrm{T} 3$ & 51 & 15.7 \\
\hline $\mathrm{T} 4$ & 48 & 14.8 \\
\hline \multicolumn{3}{|l|}{$\mathrm{N}$ staging } \\
\hline No & 155 & 47.8 \\
\hline N1 & 31 & 9.6 \\
\hline $\mathrm{N} 2$ & 136 & 42.0 \\
\hline N3 & 2 & 0.6 \\
\hline \multicolumn{3}{|l|}{ Histology } \\
\hline Adenocarcinoma & 230 & 71.0 \\
\hline Squamous & 94 & 29.0 \\
\hline \multicolumn{3}{|c|}{ Adjuvant chemotherapy } \\
\hline Yes & 156 & 45.3 \\
\hline No & 188 & 54.7 \\
\hline
\end{tabular}

tion was observed in other comparisons (Figure 4; Supplementary Table 3).

Prognosis. The last follow-up date for all patients was May 31, 2019. At that time, 217 patients died and 107 patients were alive. OS was calculated from the surgical date to the date of death. We analyzed the association of clinicopathological characteristics (age, gender, smoking, TNM stage, $\mathrm{T}$ stage, $\mathrm{N}$ stage, and histology), immune markers (density of tumor $\mathrm{S}^{2} 5^{+}$cells, density of $\mathrm{CD}^{+} \mathrm{T}$ cells in tumor and stroma, density of FOXP3 ${ }^{+} \mathrm{T}$ cells in tumor and stroma, and tumor PD-L1 expression), and adjuvant chemotherapy with outcomes of patients. In univariate analysis, we found that age $<60$ years old $(p=0.030)$, early TNM stage $(p<0.001)$, early $\mathrm{T}$ stage $(\mathrm{p}<0.001)$, early $\mathrm{N}$ stage $(\mathrm{p}<0.001)$, the high density of tumor $\mathrm{CD}^{+} \mathrm{T}$ cells $(\mathrm{p}=0.034)$, the high density of stromal $\mathrm{CD}^{+} \mathrm{T}$ cells $(\mathrm{p}=0.037)$, the high density of stromal FOXP $^{+} \mathrm{T}$ cells $(\mathrm{p}=0.005)$, tumor low expression of PD-L1 $(\mathrm{p}=0.007)$, and receiving adjuvant chemotherapy $(\mathrm{p}=0.001)$ 


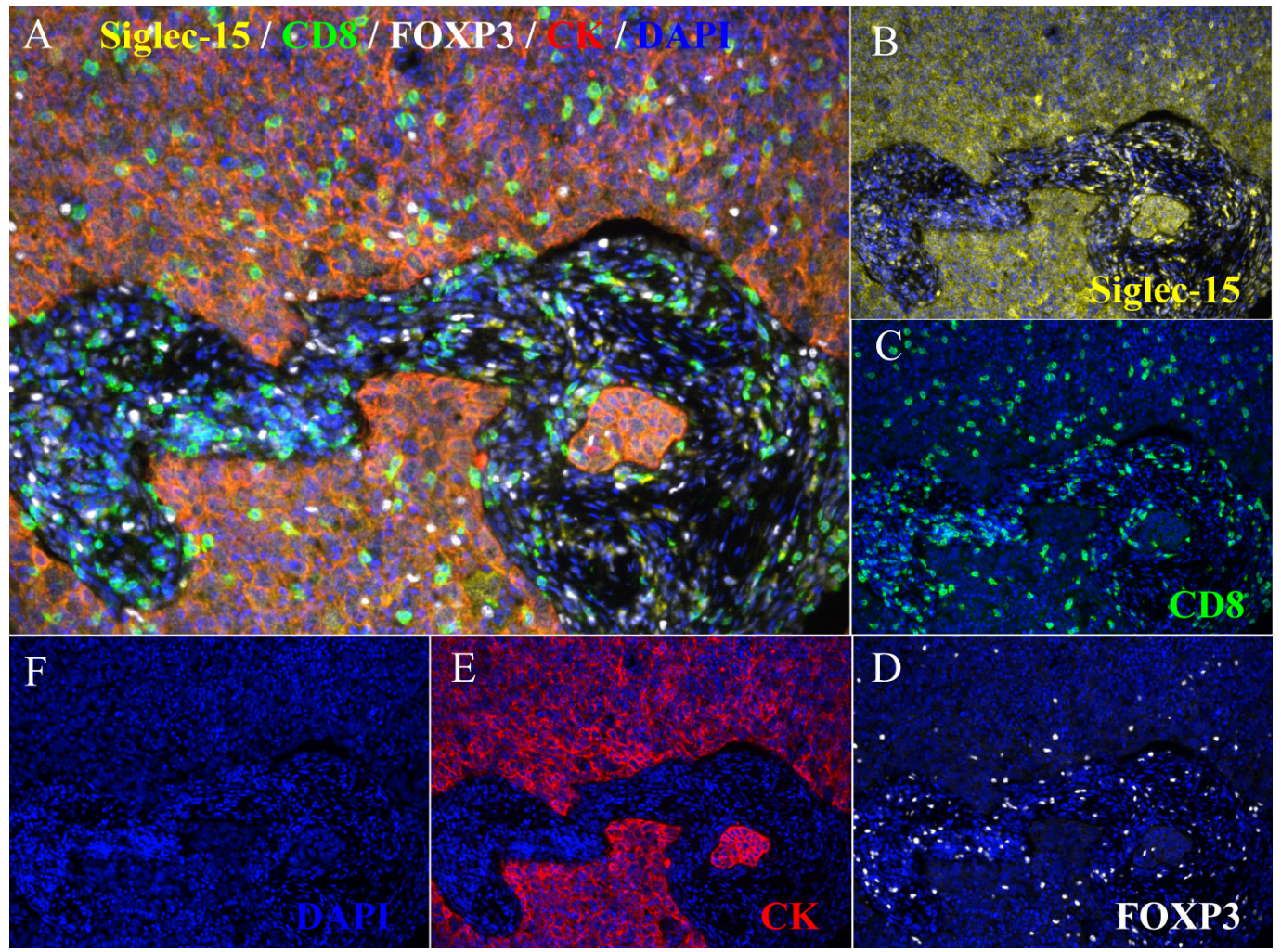

Figure 1. S15, CD8, FOXP3 expression in NSCLC by multiplex immunofluorescence staining using Opal 7-color reagents (PerkinElmer). A tumor containing tumor compartments and stromal compartment divided by CK. A) A merged picture of expression of S15, CD8, FOXP3, CK, and DAPI. B) S15 expression (yellow). C) CD8 expression (green). D) FOXP3 expression (white). E) CK expression (red). F) DAPI (blue).
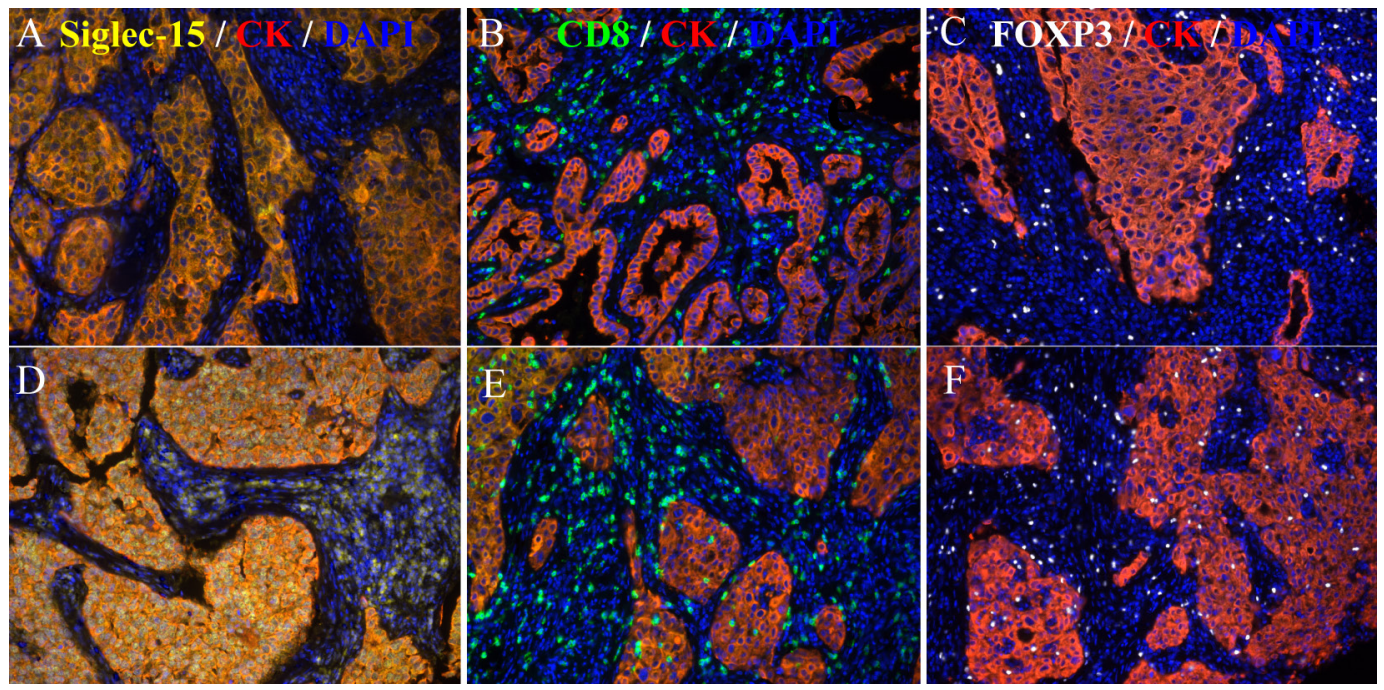

Figure 2. $\mathrm{S15}^{+}$cells, $\mathrm{CD8}^{+} \mathrm{T}$ cells, FOXP3 ${ }^{+} \mathrm{T}$ cells by multiplex immunofluorescence staining using Opal 7-color reagents (PerkinElmer). A) S15 ${ }^{+}$cells in the tumor (yellow). B) $\mathrm{CD8}^{+} \mathrm{T}$ cells in the stroma (green). C) FOXP3 ${ }^{+} \mathrm{T}$ cells in the stroma (white). D) $\mathrm{S15}^{+}$cells in tumor and stroma (yellow). E) $\mathrm{CD8}^{+} \mathrm{T}$ cells in tumor and stroma (green). F) FOXP3 ${ }^{+} \mathrm{T}$ cells in tumor and stroma (white).

were associated with better OS compared opposite factors. Factors with a significant difference in univariate analysis entered multivariate analyses based on the Cox hazard proportion ratio model. The results showed that patients with early T stage (HR $0.406,95 \%$ CI $0.296,0.555, \mathrm{p}<0.001$ ), early
$\mathrm{N}$ stage (HR $0.655,95 \% \mathrm{CI} 0.442,0.971, \mathrm{p}=0.035)$, low PD-L1 expression (HR 0.646, 95\%CI 0.426, 0.979, $\mathrm{p}=0.039$ ), and receiving adjuvant chemotherapy (HR $0.537,95 \%$ CI 0.401 , $0.718, \mathrm{p}<0.001$ ) were independent factors of OS (Figures 6, 7; Supplementary Table 4). 
Figure 3. PD-L1 expression in the tumor. PD-L1 (clone 22C3, Dako) expression was tested on Autostainer Link 48 machine (Dako North America, Inc.) combined with Dako EnVisionTM FLEX ${ }^{+}$and DAB Enhancer solution. A) Negative PD-L1 expression in lung adenocarcinoma (LUAD). B) Negative PD-L1 expression in lung squamous cell carcinoma (LUSC). C) Positive PD-L1 expression in lung adenocarcinoma (LUAD). D) Positive PD-L1 expression in lung squamous cell carcinoma (LUSC). $(\times 200)$
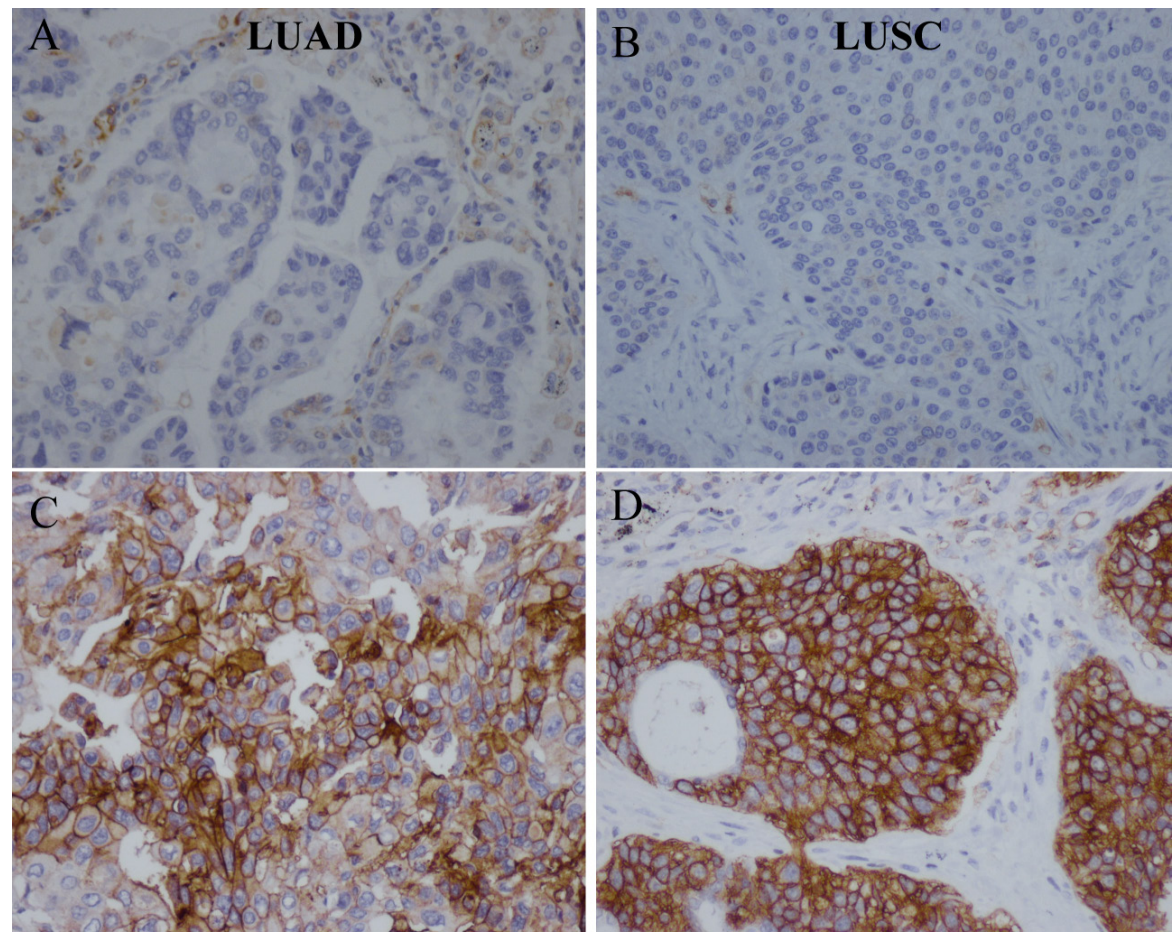

\section{Discussion}

In this study, the association of tumor S15 expression, along with CD8 and FOXP3 in TME, with the clinicopathological characteristics and outcomes in 324 NSCLC patients who underwent surgical resection using multiplex immunofluorescence staining were investigated and PD-L1 expression was also analyzed. We found that S15 expression was significantly higher in lung adenocarcinoma than that in lung squamous cell carcinoma. S15 expression was significantly positively associated with the density of stromal $\mathrm{CD}^{+}$ T cells. S15 expression was not associated with the OS of patients with resected NSCLC.

In this study, we found that S15 expression was common in lung adenocarcinoma than that in lung squamous cell carcinoma $(p=0.004)$ and not associated with other clinicopathological characteristics. The higher S15 expression in lung adenocarcinoma may show a clue that patients with adenocarcinoma may have a more chance to receive treatment of S15 inhibitors. Few studies focus on S15 expression with clinicopathological characteristics. We also found that S15 expression was not related to the OS of patients with resectable NSCLC and this is the first report on the correlation of S15 expression with the prognosis of patients with NSCLC. We found that S15 was positively related to the density of $\mathrm{CD}^{+} \mathrm{T}$ cells in the stroma, suggesting that S15 is closely related to immune cells and immune response and the specific mechanism is not clear, which remains to be further studied in the future. This is the first time for quantitative analysis of large samples of early resectable NSCLC tumor tissues and immune checkpoint $\mathrm{S} 15$ and its immune cells, especially $\mathrm{CD}^{+} \mathrm{T}$ cells and $\mathrm{FOXP}^{+} \mathrm{T}$ cells.

A previous study reported that S15 and PD-L1 expression were mutually exclusive [19]. We also investigated the relationship of S15 and PD-L1 expression in our cohort. We used a clone of PD-L1 (22C3), which is approved a companion diagnosis of pembrolizumab by the American FDA based on clinical trials in which higher PD-L1 expression was associated with better response to pembrolizumab. We found S15 expression is significantly increased in lung adenocarcinoma, a different tumor pathological histology, compared with PD-L1 increased in squamous cell carcinoma. And this phenomenon may indicate that patients with lung adenocarcinoma may have a chance of receiving the therapy of an S15 inhibitor and patients with squamous cell carcinoma are more suitable for a PD-L1/PD-L1 inhibitor. That gives a clue that $\mathrm{S} 15$ may be a complementary for immunotherapy based on PD-L1. Thus, the mechanism of co-expression of S15 and $\mathrm{PD}-\mathrm{L} 1$ is worth investigating further. PD-L1 expression was an independent factor of poor prognosis in NSCLC [24]. This is similar to a previous study that showed that PD-L1 expression is associated with an aggressive NSCLC subset and abundant $\mathrm{CD} 8^{+}$lymphocytes.

Multiple immunofluorescence staining can provide more clues about the relationship between cancer cells and TILs in the TME including co-location or co-expression [25]. The advantages of multiple immunofluorescence staining are almost absolute quantitative and present a display of TME 

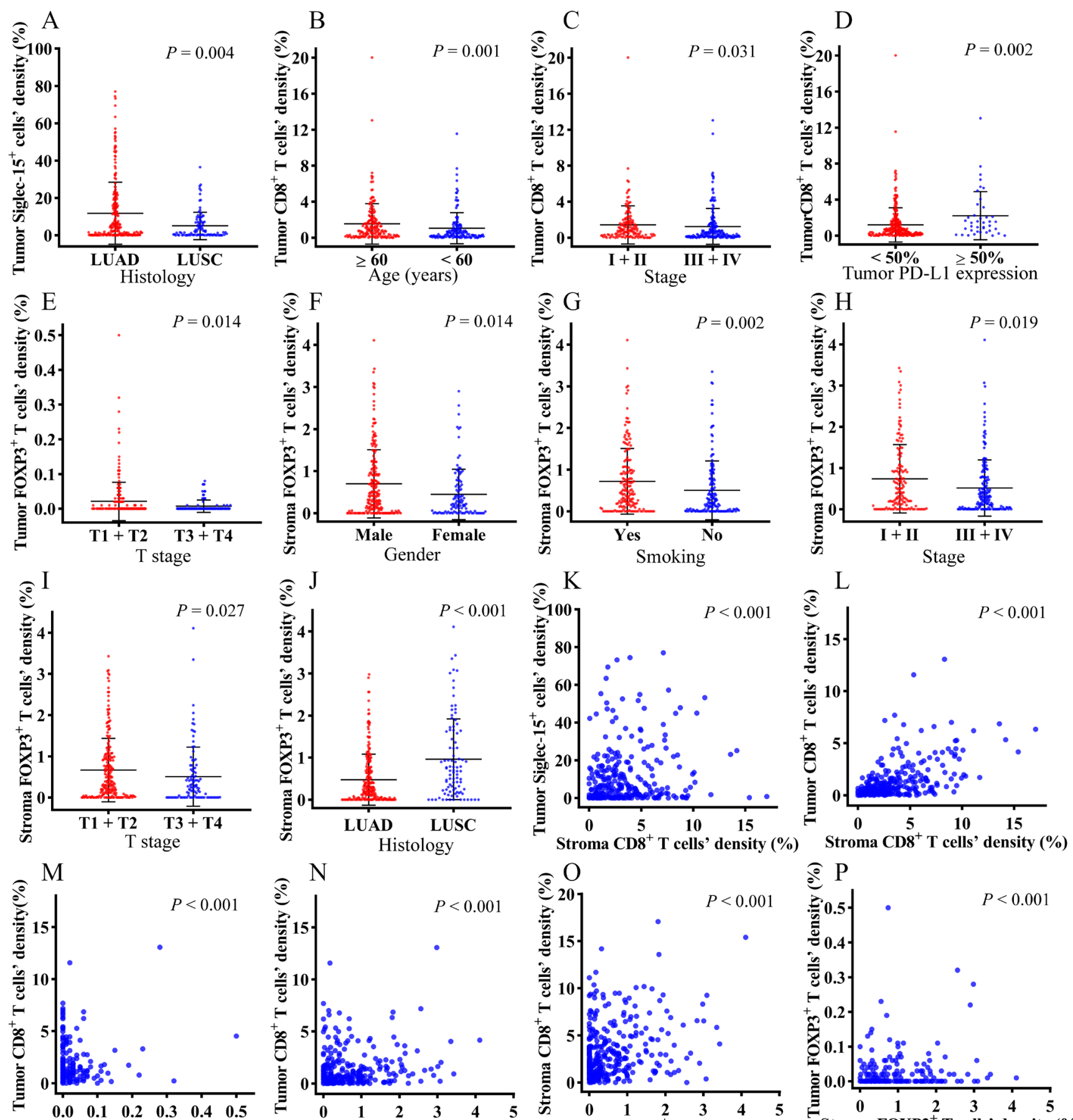

Tumor FOXP3 ${ }^{+}$T cells' density (\%)Stroma FOXP3 ${ }^{+}$T cells' density (\%) Stroma FOXP3 ${ }^{+} \mathrm{T}$ cells' density (\%) ${ }^{\prime}$ Stroma FOXP3 ${ }^{+}$T cells' density $(\%)^{\prime}$

Figure 4. Expression of S15, CD8, and FOXP3 with the clinicopathological characteristics and their correlation. A) The difference in S15 ${ }^{+}$cell density in tumors between LUAD and LUSC. B) The difference in $\mathrm{CD8}^{+} \mathrm{T}$ cell density in tumors between different age groups. C) The difference in CD8 ${ }^{+} \mathrm{T}$ cell density in tumors between early- and late-stage. $\mathrm{D})$ The difference in $\mathrm{CD8}^{+} \mathrm{T}$ cell density in tumors between PD-L1 expression positive ( $\left.\geq 50 \%\right)$ and negative $(<50 \%)$ groups. E) Differences in FOXP3 ${ }^{+} \mathrm{T}$ cell density in tumors between early and late $\mathrm{T}$ stage. F) FOXP3 $3^{+} \mathrm{T}$ cell density in stroma between male and female patients. G) FOXP3 ${ }^{+} \mathrm{T}$ cell density in stroma between smokers and non-smokers. H) FOXP3 ${ }^{+} \mathrm{T}^{+}$cell density in stroma between early-stage and late-stage. I) FOXP3 ${ }^{+} \mathrm{T}$ cell density in stroma between early and late $\mathrm{T}$ stage. J) FOXP3 ${ }^{+} \mathrm{T}_{\text {cell }}$ density in stroma between lung adenocarcinoma (LUAD) and lung squamous cell carcinoma (LUSC). K) Correlation between densities of $\mathrm{S}^{+} 5^{+}$cells and CD8 ${ }^{+} \mathrm{T}$ cells in the stroma. $\mathrm{L}$ ) Correlation between densities of $\mathrm{CD8}^{+} \mathrm{T}$ cells in tumor and stroma. M) Correlation between densities of $\mathrm{CD8}^{+} \mathrm{T}_{\text {cells and }} \mathrm{FOXP3}^{+} \mathrm{T}$ cells in the tumor. $\mathrm{N}$ ) Correlation between densities of $\mathrm{CD8}^{+} \mathrm{T}$ cells in the tumor and $\mathrm{FOXP3}^{+} \mathrm{T}$ cells in the stroma. $\mathrm{O}$ ) Correlation between densities of $\mathrm{CD}^{+} \mathrm{T}$ cells in the stroma and FOXP3 ${ }^{+} \mathrm{T}$ cells in the stroma. $\mathrm{P}$ ) Correlation between densities of FOXP3 ${ }^{+} \mathrm{T}$ cells in the tumor and FOXP3 ${ }^{+} \mathrm{T}$ cells in the stroma. 
more accurately; it is well controlled and less influenced by observers. On the other hand, there are some shortcomings, such as requirements for special equipment and software, time-consuming experimental procedure, and inconstant threshold values.

Our study has some limitations. First of all, this is a retrospective study focusing on early resectable NSCLC tissues, which does not represent the situation of middle- and latestage tumors. Secondly, the patients involved in this study had no history of immunotherapy, so these markers could
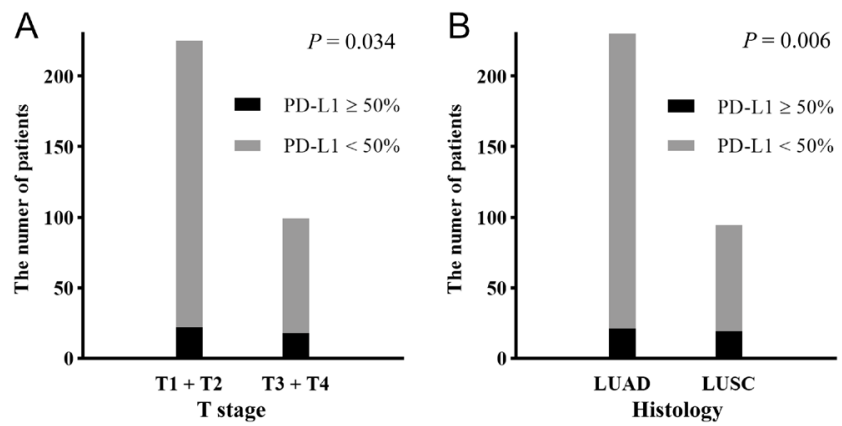

Figure 5. Expression of PD-L1. A) PD-L1 expression in different T stage group. B) PD-L1 expression in lung adenocarcinoma (LUAD) and lung squamous cell carcinoma (LUSC). not show the values after immunotherapy. Third, TMA is a part of the whole tumor tissue, which may need more in-depth and rich research data in larger tumors.

A
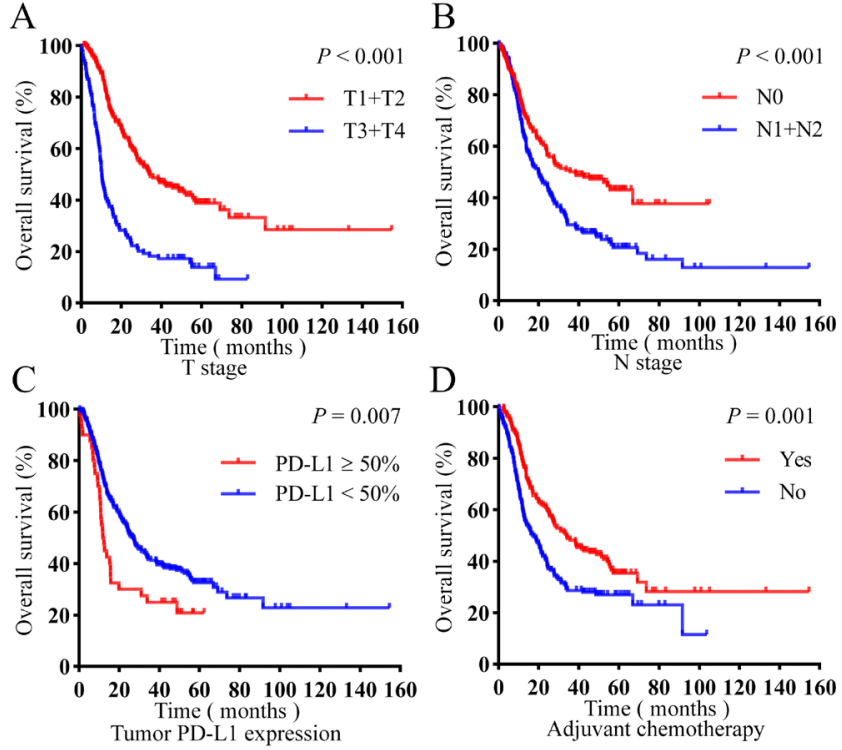

Figure 6. OS curves of patients using Kaplan-Meier. A) According to the T stage. B) According to the $\mathrm{N}$ stage. C) According to the PD-L1 expression level. D) According to the adjuvant chemotherapy.

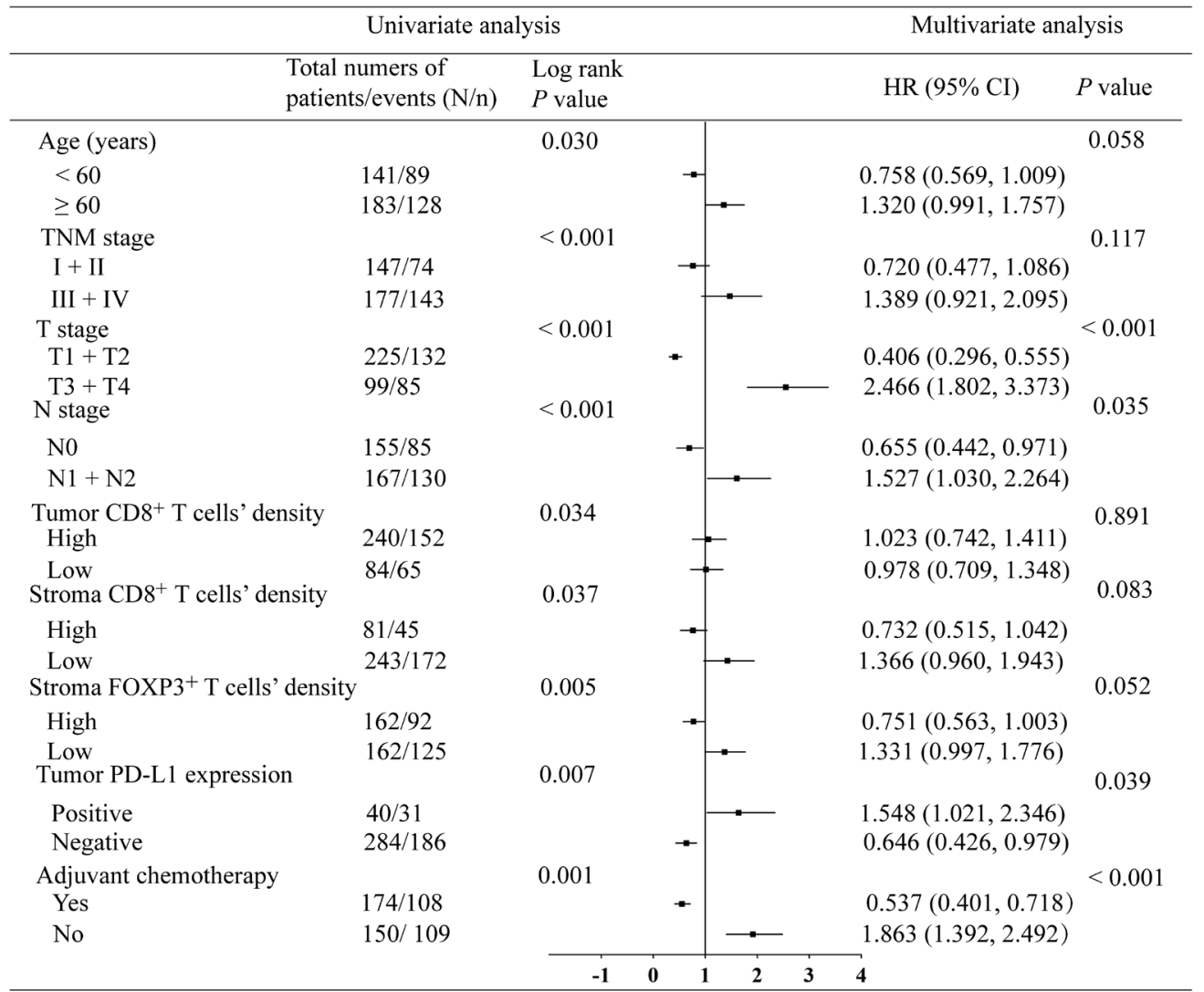

Figure 7. Subgroup analyses of OS among 324 patients with resected NSCLC by univariate and multivariate analysis. 
In conclusion, we demonstrated that S15 expression is frequently expressed in lung adenocarcinoma and has a positive correlation with the density of $\mathrm{CD}^{+} \mathrm{T}$ cells in the stroma. We found no correlation between S15 expression and overall survival in a large resected NSCLC sample size. In addition to S15 and PD-L1 signaling pathways, potential mechanisms of cancer immune escape are worthy of further studies. Quantitative immunohistochemical analysis is a potential tool for further research on lung cancer microenvironment. It may provide more clues to the immune regulation of tumor microenvironment and guide the precision immunotherapy in lung cancer.

Supplementary information is available in the online version of the paper.

Acknowledgments: We thank other colleagues and members in the Department of Pathology and Laboratories of Beijing Chest Hospital for experiment assistance. This study was supported by the Lung Cancer Project from Beijing Municipal Health Commission 362 (2017-2019).

\section{References}

[1] HIRSCH FR, SUDA K, WIENS J, BUNN PA JR. New and emerging targeted treatments in advanced non-smallcell lung cancer. Lancet 2016; 388: 1012-1024. https://doi. org/10.1016/S0140-6736(16)31473-8

[2] HIRSCH FR, SCAGLIOTTI GV, MULSHINE JL, KWON R, CURRAN WJ JR et al. Lung cancer: current therapies and new targeted treatments. Lancet 2017; 389: 299-311. https:// doi.org/10.1016/S0140-6736(16)30958-8

[3] HELLMANN MD, PAZ-ARES L, BERNABE CARO R, ZURAWSKI B, KIM SW et al. Nivolumab plus Ipilimumab in advanced non-small-cell lung cancer. N Engl J Med 2019, 381: 2020-2031. https://doi.org/10.1056/NEJMoa1910231

[4] READY N, HELLMANN MD, AWAD MM, OTTERSON GA, GUTIERREZ $M$ et al. First-line Nivolumab plus Ipilimumab in advanced non-small-cell lung cancer (CheckMate 568): outcomes by programmed death ligand 1 and tumor mutational burden as biomarkers. J Clin Oncol 2019; 37: 992-1000. https://doi.org/10.1200/JCO.18.01042

[5] WEST H, MCCEOD M, HUSSEINM, MORABITO A, RITTMEYER A et al. Atezolizumab in combination with carboplatin plus nab-paclitaxel chemotherapy compared with chemotherapy alone as first-line treatment for metastatic non-squamous non-small-cell lung cancer (IMpower130): a multicentre, randomised, open-label, phase 3 trial. Lancet Oncol 2019; 20: 924-937. https://doi.org/10.1016/S14702045(19)30167-6

[6] HORN L, MANSFIELD AS, SZCZESNA AHAVEL L, KRZAKOWSKI M et al. First-Line Atezolizumab plus chemotherapy in extensive-stage small cell lung cancer. N Engl J Med 2018; 379: 2220-2229. https://doi.org/10.1056/NEJMoa1809064
[7] SOCINSKI MA, JOTTE RM, CAPPUZZO F, ORLANDI F, STROYAKOVSKIY D et al. Atezolizumab for first-line treatment of metastatic nonsquamous NSCLC. N Engl J Med 2018; 378: 2288-2301. https://doi.org/10.1056/NEJMoa1716948

[8] RECKM, RODRIGUEZ-ABREU D, ROBINSON AG, HUI $\mathrm{R}$, CSOSZI $\mathrm{T}$ et al. Pembrolizumab versus chemotherapy for PD-L1-positive non-small-cell lung cancer. N Engl J Med 2016; 375: 1823-1833. https://doi.org/10.1056/NEJMoa1606774

[9] GANDHI L, RODRIGUEZ D, GADGEEL S, ESTEBAN E, FELIP E et al. Pembrolizumab plus chemotherapy in metastatic non-small-cell lung cancer. N Engl J Med 2018; 378: 2078-2092. https://doi.org/10.1056/NEJMoa1801005

[10] PAZ-ARES L, LUFT A, VICENTE D, TAFRESHI A, GUMUS $M$ et al. Pembrolizumab plus chemotherapy for squamous non-small-cell lung cancer. N Engl J Med 2018; 379: 2040-2051. https://doi.org/10.1056/NEJMoa1810865

[11] BORGHAEI H, PAZ-ARES L, HORN L, SPIGEL DR, STEINS $\mathrm{M}$ et al. Nivolumab versus Docetaxel in advanced nonsquamous non-small-cell lung cancer. N Engl J Med 2015; 373: 1627-1639. https://doi.org/10.1056/NEJMoa1507643

[12] BRAHMER J, RECKAMPK L, BAAS P, CRINO L, EBERHARDT WEE et al. Nivolumab versus Docetaxel in advanced squamous cell non-small-cell lung cancer. N Engl J Med 2015; 373: 123-135. https://doi.org/10.1056/NEJMoa 1504627

[13] GARON EB, HELLMANN MD, RIZVI NA, CARCERENY E, LEIGHl NB et al. Five-year overall survival for patients with advanced non-small-cell lung cancer treated with Pembrolizumab: results from the phase I KEYNOTE-001 study. J Clin Oncol 2019; 37: 2518-2527. https://doi.org/:10.1200/ JCO.19.00934

[14] LEIGHI NB, HELLMANN MD, HUI R, CARCERENY E, FELIP E et al. Pembrolizumab in patients with advanced non-small-cell lung cancer (KEYNOTE-001): 3-year results from an open-label, phase 1 study. Lancet Respir Med 2019; 7: 347-357. https://doi.org/10.1016/S2213-2600(18)30500-9

[15] CARBONE DP, RECK M, PAZ-ARES L, CREELAN B, HORN L et al. First-line Nivolumab in stage IV or recurrent non-small-cell lung cancer. N Engl J Med 2017; 376: 24152426. https://doi.org/10.1056/NEJMoa1613493

[16] SHARMA P, ALLISON JP. Immune checkpoint targeting in cancer therapy: toward combination strategies with curative potential. Cell 2015; 161: 205-214. https://doi.org/10.1016/j. cell.2015.03.030

[17] TAUBE JM, ANDERS RA, YOUNG GD, XU H, SHARMA $\mathrm{R}$ et al. Colocalization of inflammatory response with B7-h1 expression in human melanocytic lesions supports an adaptive resistance mechanism of immune escape. Sci Transl Med 2012; 4: 127-137. https://doi.org/10.1126/scitranslmed.3003689

[18] ZHANG Y, CHEN L. Classification of advanced human cancers based on tumor immunity in the microenvironment (TIME) for Cancer Immunotherapy. JAMA Oncol 2016; 2: 1403-1404. https://doi.org/10.1001/jamaoncol.2016.2450 
[19] WANG J, SUN J, LIU LN, FLIES DB, NIE X et al. Siglec-15 as an immune suppressor and potential target for normalization cancer immunotherapy. Nat Med 2019; 25: 656-666. https://doi.org/10.1038/s41591-019-0374-x

[20] AMIN MB, GREENE FL, EDGE SB, COMPTON CC, GERSHENWALD JE et al. The eighth edition AJCC cancer staging manual: continuing to build a bridge from a populationbased to a more "personalized" approach to cancer staging. CA Cancer J Clin 2017; 67: 93-99. https://doi.org/10.3322/ caac. 21388

[21] TRAVIS WD, BRAMBILLA E, BURKE AP, MARX A, NICHOLSON AG. Introduction to the 2015 World Health Organization classification of tumors of the lung, pleura, thymus, and heart. J Thorac Oncol 2015; 10: 1240-1242. https:// doi.org/10.1097/JTO.0000000000000663

[22] WANG J, CAI Y, DONG Y, NONG J, ZHOU L et al. Clinical characteristics and outcomes of patients with primary lung adenocarcinoma harboring ALK rearrangements detected by FISH, IHC, and RT-PCR. PLoS One 2014; 9: e101551. https://doi.org/10.1371/journal.pone.0101551
[23] STACK EC, WANG C, ROMAN KA, HOYT CC. Multiplexed immunohistochemistry, imaging, and quantitation: a review, with an assessment of Tyramide signal amplification, multispectral imaging and multiplex analysis. Methods 2014; 70: 46-58. https://doi.org/10.1016/j. ymeth.2014.08.016

[24] ZHOU C, TANG J, SUN H, ZHENG X, LI Z et al. PD-L1 expression as poor prognostic factor in patients with nonsquamous non-small cell lung cancer. Oncotarget 2017; 8, 58457-58468. https://doi.org/10.18632/oncotarget.17022

[25] VILLARROEL-ESPINDOLA F, YU X, DATAR I, MANI N, SANMAMED $\mathrm{M}$ et al. Spatially resolved and quantitative analysis of VISTA/PD-1H as a novel immunotherapy target in human non-small cell lung cancer. Clin Cancer Res 2018, 24, 1562-1573. https://doi.org/10.1158/1078-0432.CCR-172542 


\section{The significance of Siglec-15 expression in resectable non-small cell lung cancer}

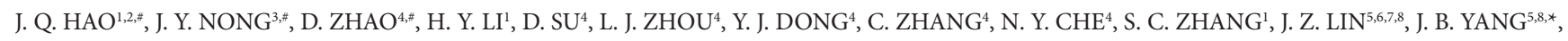
H. T. ZHANG ${ }^{9, *}$, J. H. WANG ${ }^{1, *}$

\section{Supplementary Information}

Supplementary Table 1. The correlation between densities of Siglec-15, CD8+ T cells, and FOXP3+ T cells with clinicopathological characteristics.

\begin{tabular}{|c|c|c|c|c|c|c|c|c|c|c|c|}
\hline & \multirow{2}{*}{$\mathbf{N}$} & \multicolumn{2}{|c|}{$\begin{array}{l}\text { Siglec- } 15^{+} \text {cells density } \\
\text { in tumor }\end{array}$} & \multicolumn{2}{|c|}{$\begin{array}{l}\mathrm{CD8}^{+} \text {cells density } \\
\text { in tumor }\end{array}$} & \multicolumn{2}{|c|}{$\begin{array}{l}\mathrm{CD8}^{+} \text {cells density } \\
\text { in stroma }\end{array}$} & \multicolumn{2}{|c|}{$\begin{array}{l}\text { FOXP3 }^{+} \text {cells density } \\
\text { in tumor }\end{array}$} & \multicolumn{2}{|c|}{$\begin{array}{l}\text { FOXP }^{+} \text {cells' density } \\
\text { in stroma }\end{array}$} \\
\hline & & $\underset{(\%)}{\operatorname{Mean} \pm \mathrm{SD}}$ & p-value & $\begin{array}{c}\text { Mean } \pm \text { SD } \\
(\%)\end{array}$ & p-value & $\begin{array}{c}\text { Mean } \pm \text { SD } \\
(\%)\end{array}$ & p-value & $\begin{array}{c}\text { Mean } \pm \text { SD } \\
(\%)\end{array}$ & p-value & $\begin{array}{l}\operatorname{Mean} \pm \mathrm{SD} \\
(\%)\end{array}$ & p-value \\
\hline \multicolumn{12}{|l|}{ Age (year) } \\
\hline$<60$ & 141 & $11.10 \pm 15.59$ & 0.299 & $1.03 \pm 1.73$ & 0.001 & $3.00 \pm 2.84$ & 0.172 & $0.01 \pm 0.04$ & 0.067 & $0.53 \pm 0.65$ & 0.215 \\
\hline$\geq 60$ & 183 & $8.84 \pm 14.19$ & & $1.52 \pm 2.25$ & & $3.49 \pm 3.06$ & & $0.02 \pm 0.06$ & & $0.68 \pm 0.83$ & \\
\hline \multicolumn{12}{|l|}{ Gender } \\
\hline Male & 218 & $8.90 \pm 13.46$ & 0.163 & $1.32 \pm 2.16$ & 0.344 & $3.31 \pm 3.02$ & 0.915 & $0.02 \pm 0.05$ & 0.651 & $0.70 \pm 0.81$ & 0.014 \\
\hline Female & 106 & $11.71 \pm 17.24$ & & $1.30 \pm 1.81$ & & $3.22 \pm 2.90$ & & $0.02 \pm 0.04$ & & $0.45 \pm 0.60$ & \\
\hline \multicolumn{12}{|l|}{ Smoking } \\
\hline Yes & 173 & $9.02 \pm 13.42$ & 0.521 & $1.46 \pm 2.34$ & 0.651 & $3.49 \pm 3.10$ & 0.211 & $0.02 \pm 0.05$ & 0.501 & $0.72 \pm 0.79$ & 0.002 \\
\hline No & 151 & $10.75 \pm 16.31$ & & $1.13 \pm 1.65$ & & $3.04 \pm 2.82$ & & $0.02 \pm 0.04$ & & $0.50 \pm 0.71$ & \\
\hline \multicolumn{12}{|l|}{ Stage } \\
\hline I+II & 147 & $9.57 \pm 14.82$ & 0.324 & $1.40 \pm 2.12$ & 0.031 & $3.63 \pm 3.15$ & 0.053 & $0.02 \pm 0.06$ & 0.051 & $0.74 \pm 0.83$ & 0.019 \\
\hline III+IV & 177 & $10.03 \pm 14.89$ & & $1.23 \pm 1.99$ & & $2.99 \pm 2.80$ & & $0.01 \pm 0.03$ & & $0.52 \pm 0.68$ & \\
\hline \multicolumn{12}{|l|}{ T stage } \\
\hline $\mathrm{T} 1+\mathrm{T} 2$ & 225 & $10.34 \pm 15.18$ & 0.336 & $1.35 \pm 1.87$ & 0.041 & $3.46 \pm 3.03$ & 0.054 & $0.02 \pm 0.06$ & 0.014 & $0.67 \pm 0.77$ & 0.027 \\
\hline $\mathrm{T} 3+\mathrm{T} 4$ & 99 & $8.64 \pm 14.02$ & & $1.22 \pm 2.43$ & & $2.87 \pm 2.81$ & & $0.01 \pm 0.02$ & & $0.50 \pm 0.72$ & \\
\hline \multicolumn{12}{|l|}{$\mathrm{N}$ stage } \\
\hline N0 & 155 & $9.94 \pm 15.17$ & 0.546 & $1.31 \pm 2.07$ & 0.222 & $3.57 \pm 3.14$ & 0.114 & $0.02 \pm 0.05$ & 0.246 & $0.67 \pm 0.78$ & 0.507 \\
\hline $\mathrm{N} 1+\mathrm{N} 2$ & 167 & $9.81 \pm 14.63$ & & $1.32 \pm 2.05$ & & $3.02 \pm 2.81$ & & $0.02 \pm 0.04$ & & $0.58 \pm 0.74$ & \\
\hline \multicolumn{12}{|l|}{ Histology } \\
\hline Adenocarcinoma & 230 & $5.01 \pm 7.31$ & 0.004 & $1.34 \pm 1.66$ & 0.908 & $3.62 \pm 3.25$ & 0.347 & $0.01 \pm 0.02$ & 0.253 & $0.96 \pm 0.96$ & $<0.001$ \\
\hline Squamous & 94 & $11.79 \pm 16.59$ & & $1.30 \pm 2.19$ & & $3.14 \pm 2.85$ & & $0.02 \pm 0.05$ & & $0.48 \pm 0.61$ & \\
\hline \multicolumn{12}{|l|}{ PD-L1 expression } \\
\hline Positive & 40 & $4.77 \pm 8.48$ & 0.090 & $2.21 \pm 2.68$ & 0.002 & $3.36 \pm 2.67$ & 0.546 & $0.02 \pm 0.05$ & 0.139 & $0.92 \pm 1.06$ & 0.084 \\
\hline Negative & 284 & $10.53 \pm 15.40$ & & $1.18 \pm 1.92$ & & $3.27 \pm 3.02$ & & $0.02 \pm 0.05$ & & $0.58 \pm 0.70$ & \\
\hline
\end{tabular}




\begin{tabular}{lccc}
$\begin{array}{l}\text { Supplementary Table 2. The correlation between tumor PD-L1 expres- } \\
\text { sion with clinicopathological characteristics. }\end{array}$ & $\begin{array}{c}\text { Tumor PD-L1 } \\
\text { expression } \\
\text { positive, N (\%) }\end{array}$ & $\begin{array}{c}\text { Tumor PD-L1 } \\
\text { expression } \\
\text { negative, N (\%) }\end{array}$ & p-value \\
\hline Variables & $14(9.9)$ & $127(90.1)$ & 0.246 \\
\hline $\begin{array}{l}\text { Age (years) } \\
<60\end{array}$ & $26(14.2)$ & $157(85.8)$ & \\
$\quad \geq 60$ & $31(14.2)$ & $187(85.8)$ & 0.141 \\
Gender & $9(8.5)$ & $97(91.5)$ & \\
$\quad$ Male & $16(10.6)$ & $135(89.4)$ & 0.371 \\
Female & $24(13.9)$ & $149(86.1)$ & \\
Smoking status & & & \\
Non-smoking & $17(11.6)$ & $130(88.4)$ & 0.697 \\
Current smoking & $23(13.0)$ & $154(87.0)$ & \\
Stage & & & \\
I+II & & & \\
III+IV & $22(9.8)$ & $203(90.2)$ & 0.034 \\
T stage & $18(18.2)$ & $81(81.8)$ & \\
T1+T2 & & & \\
T3+T4 & $17(11.0)$ & $138(89.0)$ & 0.446 \\
N stage & $23(13.8)$ & $144(86.2)$ & \\
N0 & & & \\
N1+N2 & $21(9.1)$ & $209(90.9)$ & 0.006 \\
Histology & $19(20.2)$ & $75(79.8)$ & \\
Adenocarcinoma & & & \\
Squamous & & & \\
\hline
\end{tabular}

Supplementary Table 3. The correlation between density of Siglec- $15^{+}$cells, $\mathrm{CD8}^{+} \mathrm{T}$ cells, and FOXP3 ${ }^{+} \mathrm{T}$ cells.

\begin{tabular}{|c|c|c|c|c|c|c|c|c|c|c|}
\hline & \multicolumn{2}{|c|}{$\begin{array}{l}\text { Siglec- } 15^{+} \text {cells' density } \\
\text { in tumor }\end{array}$} & \multicolumn{2}{|c|}{$\begin{array}{l}\mathrm{CD8}^{+} \text {cells' density } \\
\text { in tumor }\end{array}$} & \multicolumn{2}{|c|}{$\begin{array}{l}\mathrm{CD8}^{+} \text {cells' density } \\
\text { in stroma }\end{array}$} & \multicolumn{2}{|c|}{$\begin{array}{l}\text { FOXP3 }^{+} \text {cells' density } \\
\text { in tumor }\end{array}$} & \multicolumn{2}{|c|}{$\begin{array}{c}\mathrm{FOXP}^{+} \text {cells' density } \\
\text { in stroma }\end{array}$} \\
\hline & $\mathbf{r}$ & p-value & $\mathbf{r}$ & p-value & $\mathbf{r}$ & p-value & $\mathbf{r}$ & p-value & $\mathbf{r}$ & p-value \\
\hline $\begin{array}{l}\text { Siglec15 } 5^{+} \text {cells' } \\
\text { density in tumor }\end{array}$ & - & - & 0.093 & 0.093 & 0.238 & $<0.001$ & -0.071 & 0.199 & 0.064 & 0.248 \\
\hline $\begin{array}{l}\mathrm{CD8}^{+} \text {cells' den- } \\
\text { sity in tumor }\end{array}$ & 0.093 & 0.093 & - & - & 0.635 & $<0.001$ & 0.286 & $<0.001$ & 0.315 & $<0.001$ \\
\hline $\begin{array}{l}\mathrm{CD8}^{+} \text {cells' den- } \\
\text { sity in stroma }\end{array}$ & 0.238 & $<0.001$ & 0.635 & $<0.001$ & - & - & 0.065 & 0.244 & 0.283 & $<0.001$ \\
\hline $\begin{array}{l}\text { FOXP3 }{ }^{+} \text {cells' } \\
\text { density in tumor }\end{array}$ & -0.071 & 0.199 & 0.286 & $<0.001$ & 0.065 & 0.244 & - & - & 0.387 & $<0.001$ \\
\hline $\begin{array}{l}\text { FOXP3 }^{+} \text {cells' } \\
\text { density in stroma }\end{array}$ & 0.064 & 0.248 & 0.315 & $<0.001$ & 0.283 & $<0.001$ & 0.387 & $<0.001$ & - & - \\
\hline
\end{tabular}


Supplementary Table 4. Univariate and multivariate analysis of overall survival.

\begin{tabular}{|c|c|c|c|c|c|}
\hline \multirow{2}{*}{ Variables } & \multirow{2}{*}{$\begin{array}{l}\text { Event/ } \\
\text { Number }\end{array}$} & \multicolumn{2}{|c|}{ Univariate analysis } & \multicolumn{2}{|c|}{ Multivariate analysis } \\
\hline & & $\begin{array}{l}\text { Median survival, } \\
\text { 95\%CI (month) }\end{array}$ & $\begin{array}{c}\text { Log rank } \\
\text { p-value }\end{array}$ & HR, 95\%CI & p-value \\
\hline \multicolumn{6}{|l|}{ Age (years) } \\
\hline$<60$ & $89 / 141$ & $33.0(21.666,44.334)$ & 0.030 & $0.758(0.569,1.009)$ & 0.058 \\
\hline$\geq 60$ & $128 / 183$ & $19.8(14.038,25.562)$ & & $1.320(0.991,1.757)$ & \\
\hline \multicolumn{6}{|l|}{ Gender } \\
\hline Male & $150 / 218$ & $21.4(16.388,26.412)$ & 0.070 & & \\
\hline Female & $67 / 106$ & $32.6(25.461,39.739)$ & & & \\
\hline \multicolumn{6}{|l|}{ Smoking status } \\
\hline Non-smoking & $99 / 151$ & $27.8(20.565,35.035)$ & 0.134 & & \\
\hline Current smoking & $118 / 173$ & $22.0(15.729,28.271)$ & & & \\
\hline \multicolumn{6}{|l|}{ TNM Stage } \\
\hline $\mathrm{I}+\mathrm{II}$ & $74 / 147$ & $51.3(-,-)$ & $<0.001$ & $0.720(0.477,1.086)$ & 0.117 \\
\hline III+IV & $143 / 177$ & $16.8(13.025,20.575)$ & & $1.389(0.921,2.095)$ & \\
\hline \multicolumn{6}{|l|}{ T stage } \\
\hline $\mathrm{T} 1+\mathrm{T} 2$ & $132 / 225$ & $34.0(23.465,44.535)$ & $<0.001$ & $0.406(0.296,0.555)$ & $<0.001$ \\
\hline $\mathrm{T} 3+\mathrm{T} 4$ & $85 / 99$ & $10.2(8.604,11.796)$ & & $2.466(1.802,3.373)$ & \\
\hline \multicolumn{6}{|l|}{$\mathrm{N}$ stage $\mathrm{e}^{\star}$} \\
\hline N0 & $85 / 155$ & $38.4(18.500,58.300)$ & $<0.001$ & $0.655(0.442,0.971)$ & 0.035 \\
\hline $\mathrm{N} 1+\mathrm{N} 2$ & $130 / 167$ & $20.0(14.064,25.936)$ & & $1.527(1.030,2.264)$ & \\
\hline \multicolumn{6}{|l|}{ Histology } \\
\hline Adenocarcinoma & $64 / 94$ & $27.7(22,394,33.006)$ & 0.129 & & \\
\hline Squamous & $153 / 230$ & $16.8(10.529,23.071)$ & & & \\
\hline \multicolumn{6}{|c|}{ Siglec- $15^{+}$cells' density in tumor } \\
\hline High & $103 / 155$ & $24.7(16.340,33.060)$ & 0.469 & & \\
\hline Low & $114 / 169$ & $24.2(17.331,31.069)$ & & & \\
\hline \multicolumn{6}{|c|}{$\mathrm{CD}^{+} \mathrm{T}$ cells' density in tumor } \\
\hline High & $152 / 240$ & $25.3(19.238,31.362)$ & 0.034 & $1.023(0.742,1.411)$ & 0.891 \\
\hline Low & $65 / 84$ & $20.4(11.615,29.185)$ & & $0.978(0.709,1.348)$ & \\
\hline \multicolumn{6}{|c|}{$\mathrm{CD}^{+} \mathrm{T}$ cells' density in stroma } \\
\hline High & $45 / 81$ & $28.0(0.000,57.446)$ & 0.037 & $0.732(0.515,1.042)$ & 0.083 \\
\hline Low & $172 / 243$ & $24.2(19.196,29.204)$ & & $1.366(0.960,1.943)$ & \\
\hline \multicolumn{6}{|c|}{$\mathrm{FOXP}^{+} \mathrm{T}$ cells density in tumor } \\
\hline High & $58 / 94$ & $25.3(18.017,32.583)$ & 0.445 & & \\
\hline Low & $159 / 230$ & $24.2(19.365,29.035)$ & & & \\
\hline \multicolumn{6}{|c|}{$\mathrm{FOXP}^{+} \mathrm{T}$ cells' density in stroma } \\
\hline High & $92 / 162$ & $27.9(17.265,38.535)$ & 0.005 & $0.751(0.563,1.003)$ & 0.052 \\
\hline Low & $125 / 162$ & $20.4(15.602,25.198)$ & & $1.331(0.997,1.776)$ & \\
\hline \multicolumn{6}{|l|}{ PD-L1 expression } \\
\hline Positive & $31 / 40$ & $11.9(9.576,14.224)$ & 0.007 & $1.548(1.021,2.346)$ & 0.039 \\
\hline Negative & $186 / 284$ & $26.6(22.175,31.025)$ & & $0.646(0.426,0.979)$ & \\
\hline \multicolumn{6}{|c|}{ Adjuvant chemotherapy } \\
\hline Yes & $108 / 174$ & $34.0(24.060,43.940)$ & 0.001 & $0.537(0.401,0.718)$ & $<0.001$ \\
\hline No & $109 / 150$ & $17.7(12.046,23.354)$ & & $1.863(1.392,2.492)$ & \\
\hline
\end{tabular}

*2 patients with $\mathrm{N} 3$ were not included due to the small size sample 